\title{
Influence of torsion on the structure of machine elements made of polymeric materials by $3 \mathrm{D}$ printing
}

\author{
Mariusz Dębski ${ }^{1)}$ (ORCID ID: 0000-0002-4889-7633), Marek Magniszewski ${ }^{2)}$ (0000-0002-9088-8159), Jacek Bernaczek ${ }^{1)}$ \\ (0000-0002-8942-092X), Łukasz Przeszłowski ${ }^{1)}$ (0000-0002-1212-9069), Małgorzata Gontarz ${ }^{1) \text {, *) }}$ (0000-0002-1803-4415), \\ Mateusz Kiełbicki ${ }^{3)}(0000-0002-8116-4589)$
}

DOI: dx.doi.org/10.14314/polimery.2021.5.3

\begin{abstract}
In this work, on the example of a spline connection, the effect of 3D printing on the structure of machine elements made of polymeric materials after a torsion test was investigated. A clear influence of the type of polymer and the printing direction in the applied incremental technology [FFF (Fused Filament Fabrication), also known as FDM (Fused Deposition Modeling)] on the structure of the obtained elements was observed.
\end{abstract}

Keywords: torsional resistance, surface morphology, polymeric materials, machine elements, incremental technologies.

\section{Wpływ skręcania na strukturę elementów maszyn wytworzonych $\mathrm{z}$ materiałów polimerowych metodą druku 3D}

Streszczenie: $\mathrm{W}$ pracy, na przykładzie połączenia wielowypustowego, zbadano wpływ druku 3D na strukturę elementów maszyn wykonanych z materiałów polimerowych po próbie skręcania. Zaobserwowano wyraźny wpływ rodzaju polimeru i kierunku druku w stosowanych technologiach przyrostowych (FFF/FDM) na strukturę otrzymanych elementów.

Słowa kluczowe: odporność na skręcanie, morfologia powierzchni, materiały polimerowe, elementy maszyn, technologie przyrostowe.

The splined connections enable the transfer of significant torsional moments with small dimensions and weight. Therefore, they are more often used in the engineering industry. These connections are used to connect hubs to shafts and to prevent relative rotation caused by torque. Incremental manufacturing techniques make it possible to produce products with complex shapes and internal structures that were previously unattainable using conventional manufacturing methods, even without additional equipment [1-4]. Incremental technologies are often used in high-tech sectors, e.g. in the automotive, aviation, railway and orthopedic industries [5-8].

In recent years, incremental technologies have been increasingly used to manufacture not only visual or

\footnotetext{
1) Rzeszow University of Technology, Faculty of Mechanical Engineering and Aeronautics, Department of Mechanical Engineering, al. Powstańców Warszawy 12, 35-959 Rzeszów, Poland.

2) Rzeszow University of Technology, Faculty of Management, al. Powstańców Warszawy 12, 35-959 Rzeszów, Poland.

3) Doctoral School of Engineering and Technical Sciences at the Rzeszow University of Technology, al. Powstańców Warszawy 12, 35-959 Rzeszów, Poland.

*) Author for correspondence: m.gontarz@prz.edu.pl
}

technological prototypes, but also full-value machine and device elements based on the Rapid Manufacturing process [9-11].

More and more data can be found on the subject of incremental manufacturing, which allow to better understand the influence of the principles of this process on the quality of manufactured elements $[12,13]$. Thanks to the development of areas such as Rapid Manufacturing or Rapid Prototyping, the time of developing new products and their improvement has been shortened [14-16].

There is also a growing demand for inexpensive and fast methods of prototyping devices, which encourages significant interest in alternative and cost-effective manufacturing techniques, such as incremental manufacturing, also in the aspect of Industry $4.0[17,18]$. Materials have different properties that, in the case of incremental technologies, are related to the printing process, including positioning the model in relation to the working platform of the prototyping device [19-21].

The quality of incrementally manufactured models, which is influenced by many parameters, including the direction of printing, is an important processing parameter in additive manufacturing. There are reports on the strength of incrementally produced elements, but they do not apply to elements practically used in machines 
T a b l e 1. Specification of filaments

\begin{tabular}{l|c|c|c|c|c}
\hline \multicolumn{1}{c|}{ Parameter } & ABS & HIPS & PA12 & PA12+CF & PC \\
\hline Diameter, mm & \multicolumn{5}{|c}{$1.75 \pm 0.05$} \\
\hline Processing temperature, ${ }^{\circ} \mathrm{C}$ & $220-270$ & $190-240$ & $240-260$ & $240-270$ & $225-240$ \\
\hline
\end{tabular}

[22-24]. Therefore, this work is focused on the influence of the printing direction and the type of polymeric material on the structure of the machine elements made of polymeric materials after torsion test.

\section{EXPERIMENTAL PART}

\section{Materials}

Acrylonitrile butadiene styrene (ABS) and high impact polystyrene (HIPS) from by Barrus Filaments (Netherlands), and polyamide 12 (PA12), polyamide 12 with carbon fiber (PA12 + CF) and polycarbonate (PC) produced by Stratasys (USA-Israel), specified in Table 1, were used as filaments.

\section{Preparation of specimens}

The view of the test sample is shown in Fig. 1 [1]. The specimens were obtained using the following machines: Prusa MK3 operating in the FFF (Fused Filament Fabrication) method and Fortus $400 \mathrm{MC}$ operating in the FDM (Fused Deposition Modeling) method. The samples were obtained for a printing angle of $45^{\circ}$ and in a horizontal and vertical orientation.

\section{Methods of testing}

The morphology of the fracture surface after the torsion test was performed using a Nikon SMZ1270 stereomicroscope. Magnifications of $5 \times$ and $50 \times$ were used. The torsion test was performed with a patent-pending original designed test stand. The view of the torsion test stand is shown in Fig. 2 [1].

\section{RESULTS AND DISCUSSION}

The torsional strength of the samples distinctly depends on the type of polymeric material, the manufacturing method, and primarily also known as the degree of filling of the layer, specified by software as a technological parameter of the incremental process [1].

Based on the results of the torsion tests of the samples for ABS copolymer manufactured in the horizontal and vertical directions relative to the working platform in the FFF technology with ABS (Table 2), it was stated that much better torque results were obtained for samples manufactured in the horizontal direction (Table 2).

In the next stage of the research, torsion tests were carried out on the samples manufactured with HIPS in the FDM technology. The results of these measurements

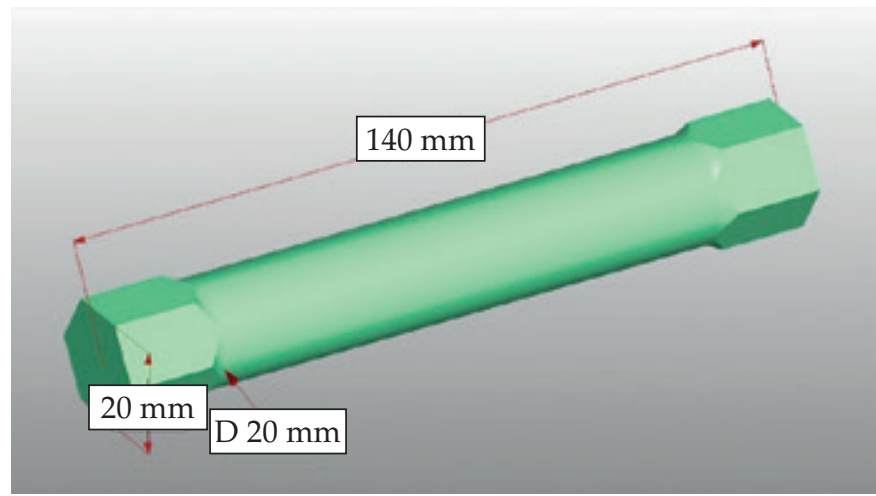

Fig. 1. Torsion test model [1]

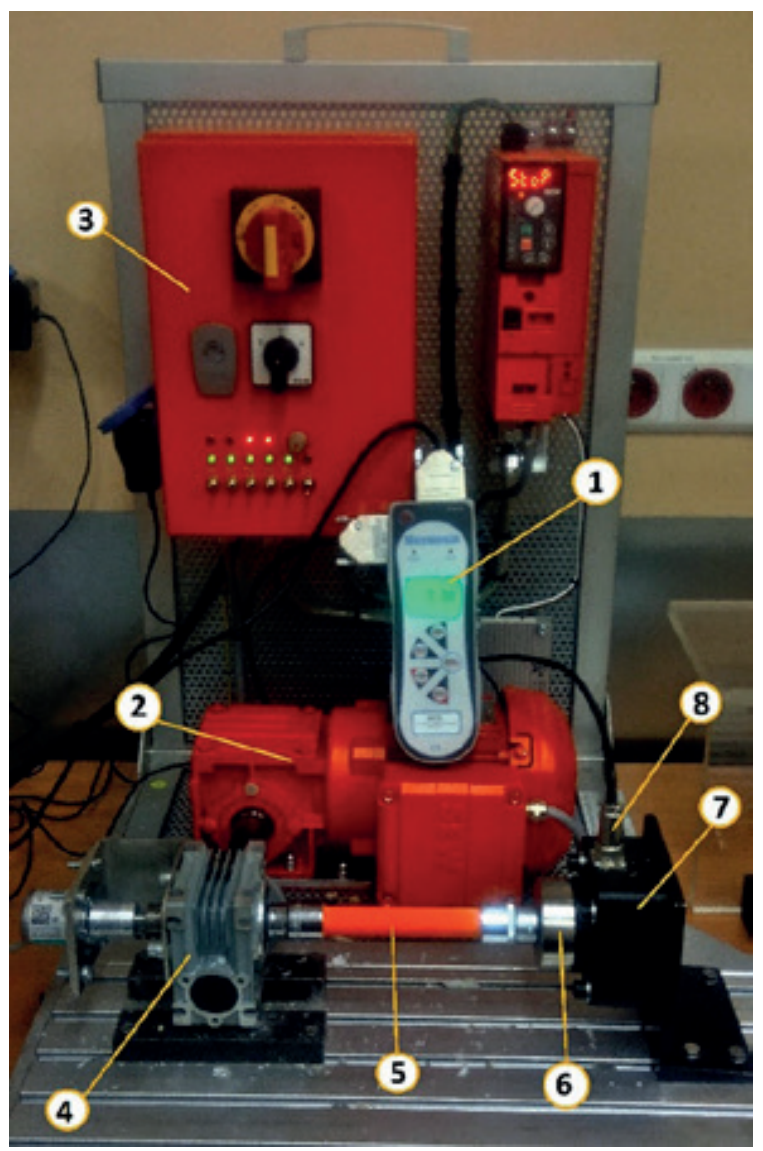

Fig. 2. Torsion test stand: 1 - torque recorder display, 2 - electric engine, 3 - control panel, 4 - shaft, 5 - test sample, 6 - sample movement sensor, 7 - measuring system, 8 - torque sensor [1]

are presented in Table 2. In this case, much better torque results were obtained for samples manufactured in the vertical direction around the working platform. This is probably due to the viscoelastic nature of HIPS.

In the next stage of the experiments, torsion tests of samples manufactured with PA12 in the FDM technology in the horizontal and vertical directions (Table 2) relative 


\begin{tabular}{c|c|c}
\hline \multirow{2}{*}{ Polymer } & \multicolumn{2}{|c}{ Torsional torque, Nm } \\
\cline { 2 - 3 } & $\begin{array}{c}\text { samples manufactured in a horizontal } \\
\text { direction relative to the working plane }\end{array}$ & $\begin{array}{c}\text { samples manufactured in a vertical } \\
\text { direction relative to the working plane }\end{array}$ \\
\hline ABS & $58.2 \pm 0.4$ & $55.6 \pm 0.2$ \\
HIPS & $38.7 \pm 0.3$ & $42.3 \pm 0.4$ \\
PA12 & $54.2 \pm 0.6$ & $51.4 \pm 0.5$ \\
PA12+CF & $70.1 \pm 0.3$ & $65.4 \pm 0.7$ \\
PC & $72.3 \pm 0.4$ & $68.7 \pm 0.5$ \\
\hline
\end{tabular}

to the working platform were tested. A slightly higher value of torque was observed for the samples manufactured in the horizontal direction.

For PA12 composites filled with carbon fiber (CF), the difference is more significant (Table 2) and it can be concluded that there is a significant impact on the orientation of model layers.

It was also observed that the best results were obtained for samples made of PC (Table 2) printed horizontally with the FFF technology. Unfortunately, there are practically no reports in the literature related to the tests of machine elements manufactured with incremental technology and loaded with torque, therefore it was not possible to relate the obtained results to the results presented in the literature.

The surface morphology of the samples fractures after the torsion tests are presented in Figs. 3-5.

Based on the analysis of the fracture surface morphology of the samples manufactured with ABS in the FFF technology, after torsion tests, the formation of a fissile fracture was observed, the surface of which was oriented perpendicular to the direction of the applied load, with no visible marks of plastic deformation. No separation of the cell layers was observed (Figs. 3a-3d). There are sharp edges on the surface of the layers that testify to a brittle fracture.

The samples manufactured with HIPS, also in the FFF technology, were subjected to observation and analysis of fractures after torsion tests. In the case of the sample obtained in the horizontal direction in relation to the working plane with HIPS in the FFF technology, a distinct separation of the layers was observed, which may testify to plastic fracture. This plastic fracturing usually ends with the separation of the material along the plane, with a maximum tangential stress function (Figs. 3e, 3f). In the case of samples manufactured in the vertical direction relative to the working platform (Figs. $3 \mathrm{~g}$, 3h), the cell layers were completely fused, and the fracture surface after the torsion test had many grooves and layer separations. This morphology may probably testify to a plastic-brittle fracture.

In the next stage of observation of the surface morphology, the samples manufactured with PA12 in the FDM technology were analyzed (Fig. 4). Based on the microscopic observation of the fracture after torsion of the sam- ples obtained in a horizontal direction (Figs. 4a, 4b), it was stated that it was a ductile cracking. The course of ductile cracking could be stopped at any time by reducing the stress below the yield strength of the material. Hence, ductile cracking did not create such a risk as a brittle break and did not occur frequently in the use of the machines and various types of devices. The cause of its formation was most often significant overloads of elements of structure up to the value of stresses close to the maximal strength of the materials. Except that it can occur due to rapid infraction of the normal condition of use of the structure, large errors in design, and strength calculations.

In the case of the fracture morphology of the samples made of PA12 obtained in the vertical direction (Figs. $4 c, 4 d)$, a separation of the cell layers was observed and their surface is ",silky” with low roughness, which proves a ductile fracture. This effect is observed when cracking is compatible with the direction of the influence of the tangential stress. It can also be certified that the addition of carbon fiber to polyamide 12 improved its torsional resistance (Table 3 ) and primarily changed the character of the fracture.

Based on the microscopic images presented in Figs. $4 \mathrm{e}-4 \mathrm{~h}$ for samples made of PA12+CF, a distinct layer structure was observed, regardless of the sample orientation relative to the working plane. Both for samples with vertical and horizontal directions, fiber presence was observed, which was arranged along the direction of layer overlap (Figs. 4e-4h) - also known as filler anisotropy. Spacing of the layers and a matt surface with high roughness was observed, which proves ductile cracking. This effect occurs when the separation of the materials propagates perpendicular to the direction of acting of the maximum tensile strength due to torsion.

In the last stage of the research, the fractures were observed after the torsion test of PC samples manufactured with the FDM technology in the horizontal and vertical directions relative to the working platform, with the images presented in Fig. 5. The surface morphology of the samples obtained in the horizontal direction indicated a separation of the layers, which is connected with plastic cracking (Figs. 5a, 5b). However, in the case of samples obtained in the vertical direction, the fracture structure is delaminated with multiple grooves, which proves, as described earlier, a plastic-brittle fracture (Figs. 5c, 5d). 

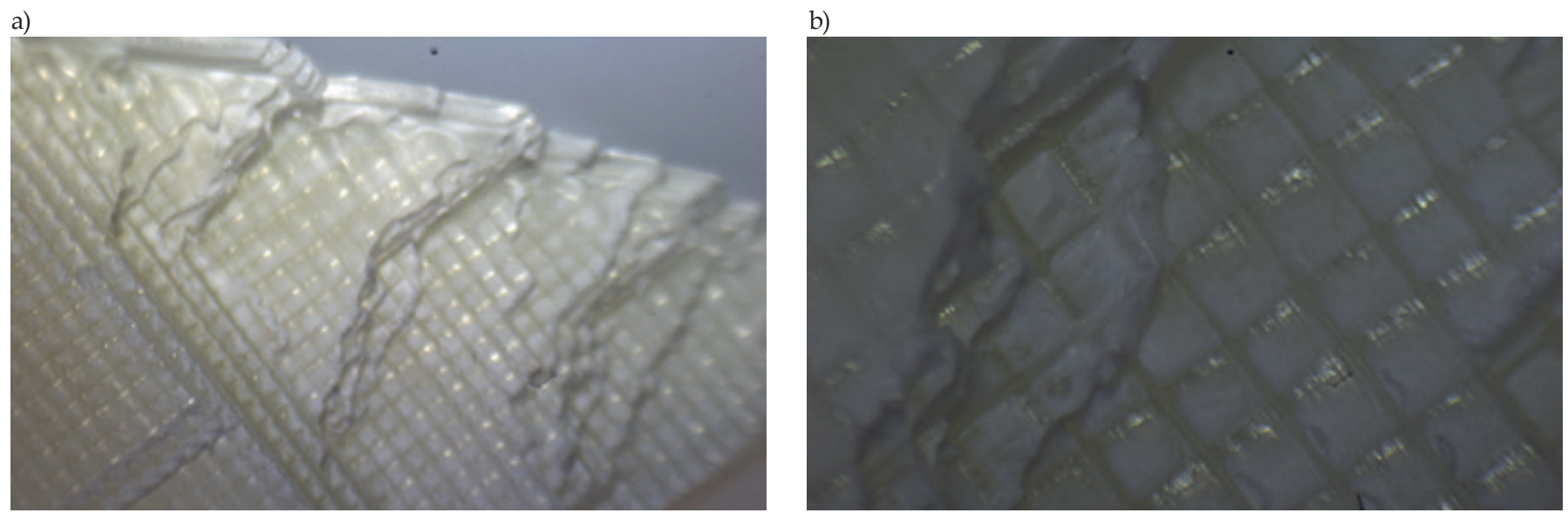

c)

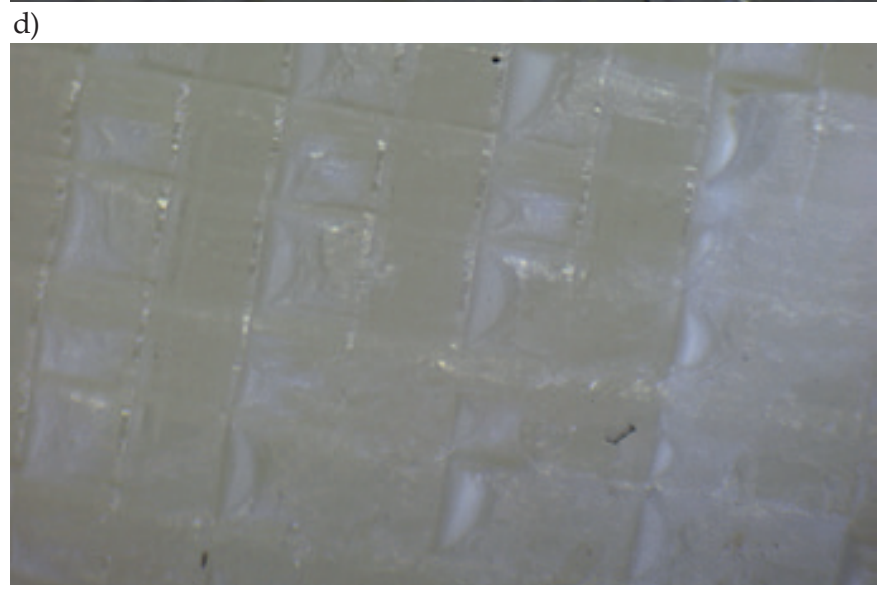

e)

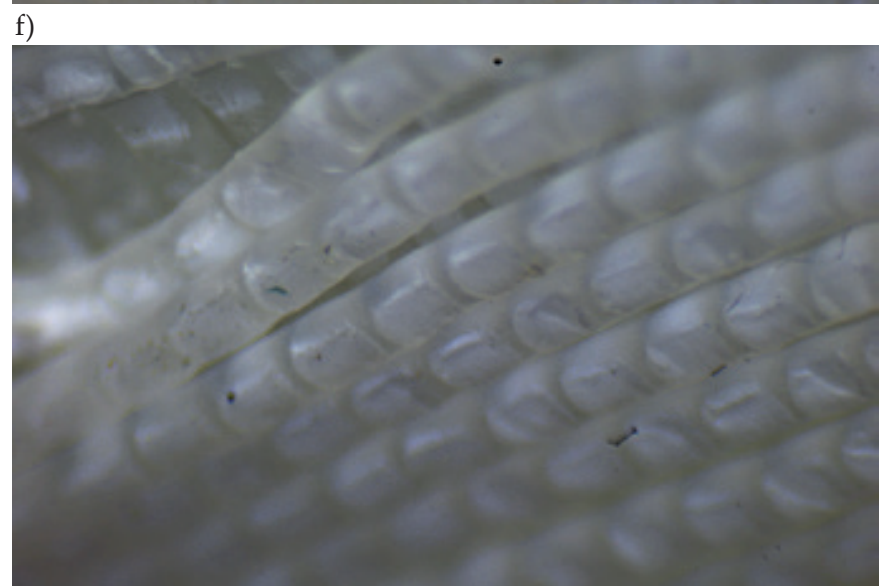

g)

h)
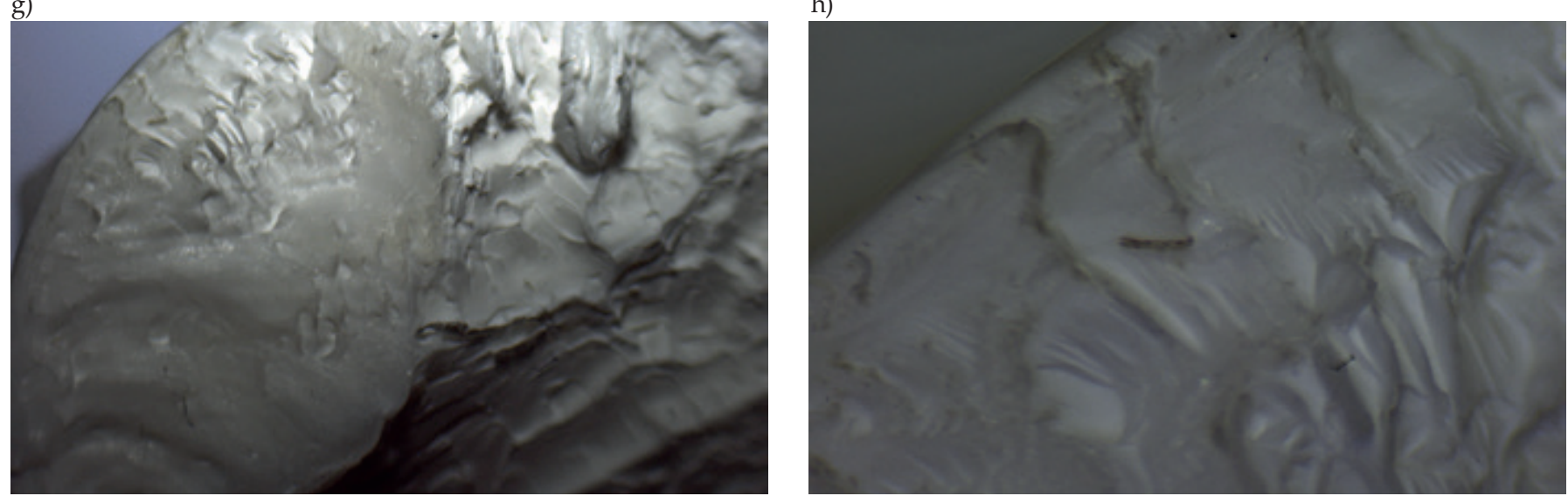

Fig. 3. Stereomicroscope images of the fracture surface after torsion test: $a, b)$ ABS sample (horizontal direction); c, d) ABS sample (vertical direction); e, f) HIPS sample (horizontal direction); g, h) HIPS sample (vertical direction) at $10 \times$ and $50 \times$ magnifications, respectively 


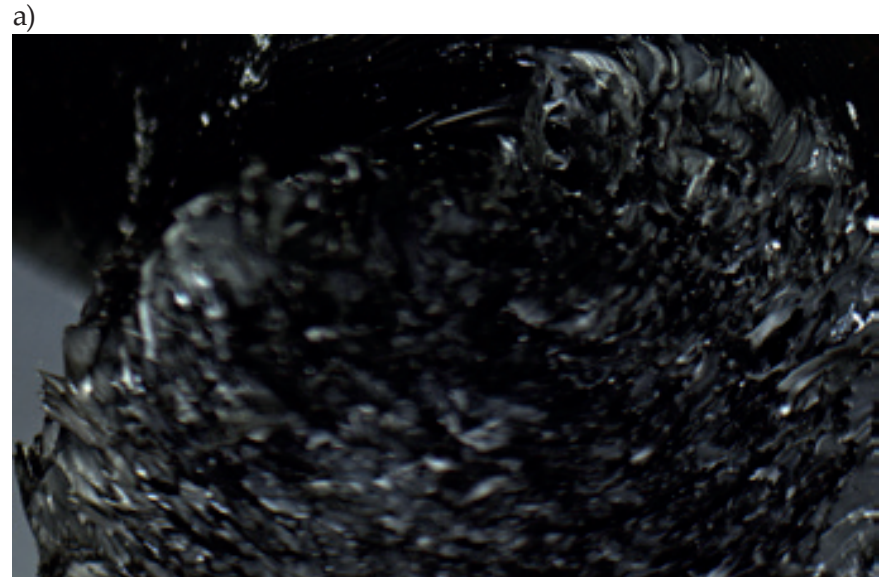

b)

c)
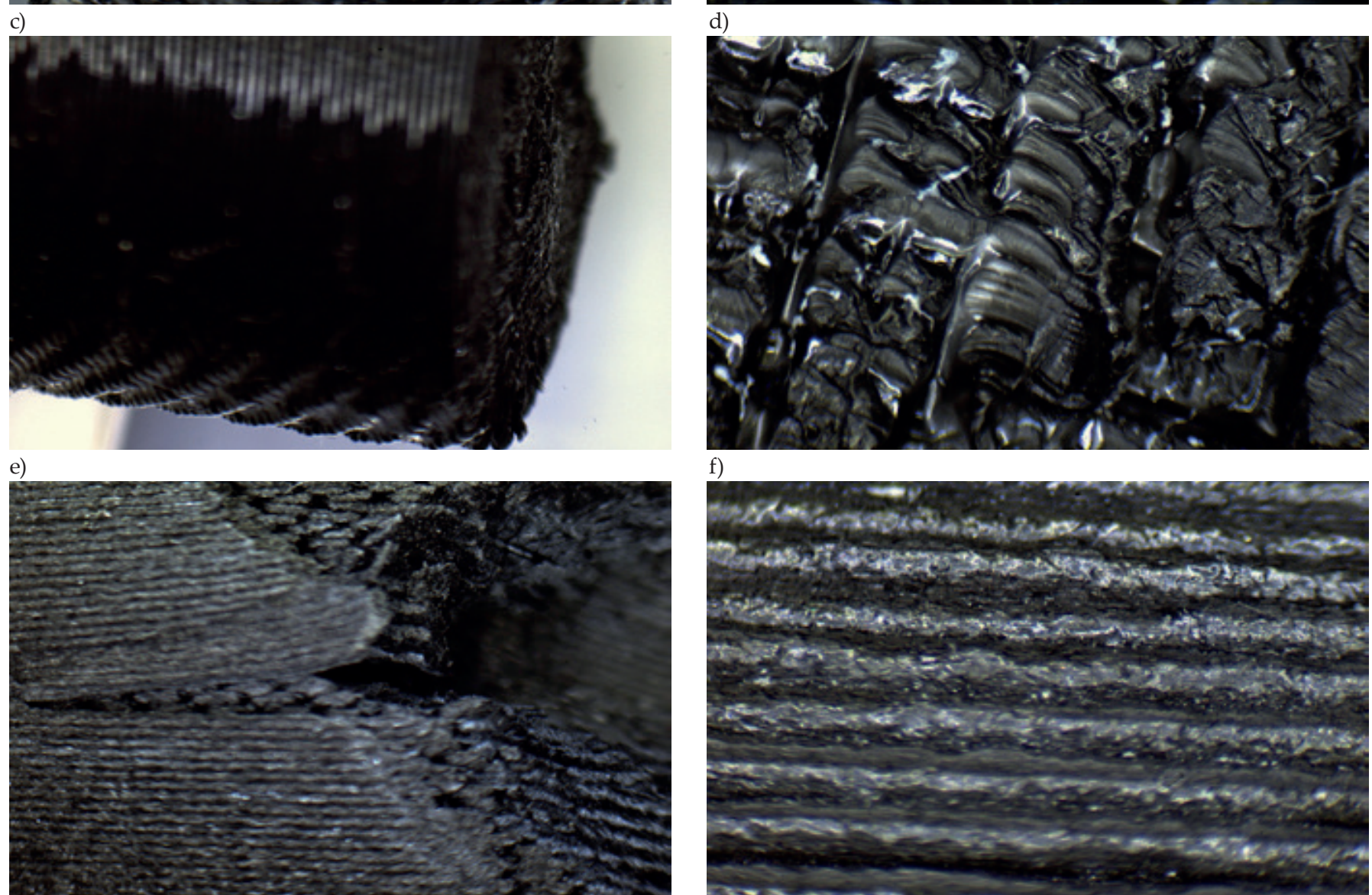

g)

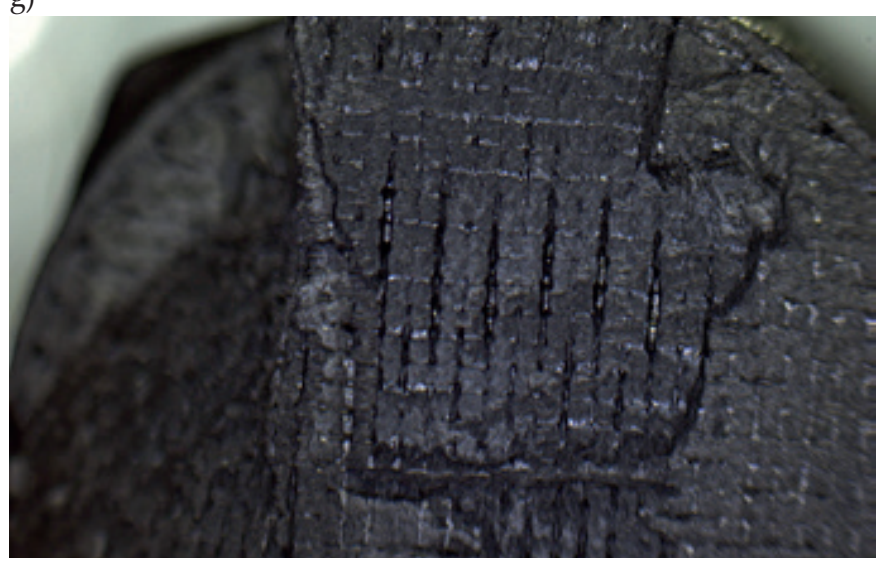

h)

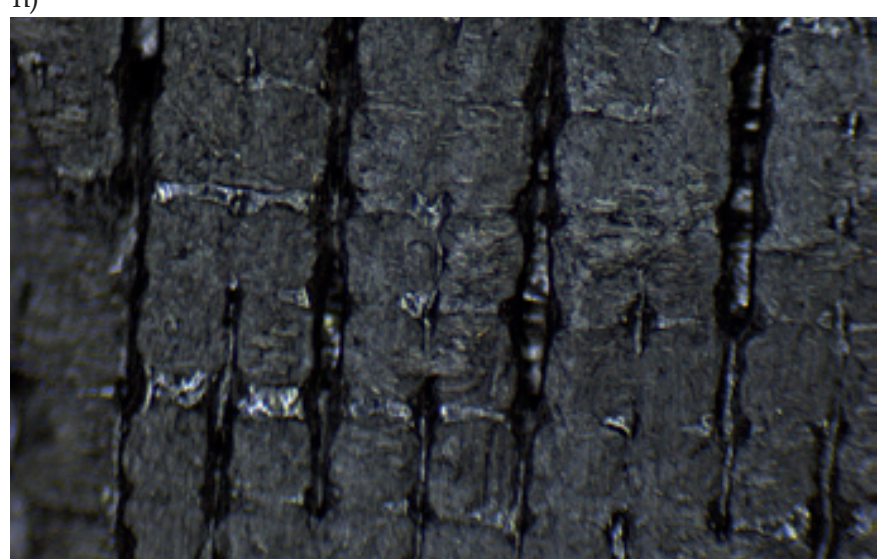

Fig. 4. Stereomicroscope images of the fracture surface after torsion test: a, b) PA12 sample (horizontal direction); c, d) PA12 sample (vertical direction); e, f) PA12 + CF sample (horizontal direction); g, h) PA12 + CF sample (vertical direction) at 10× and 50× magnifications, respectively 
a)

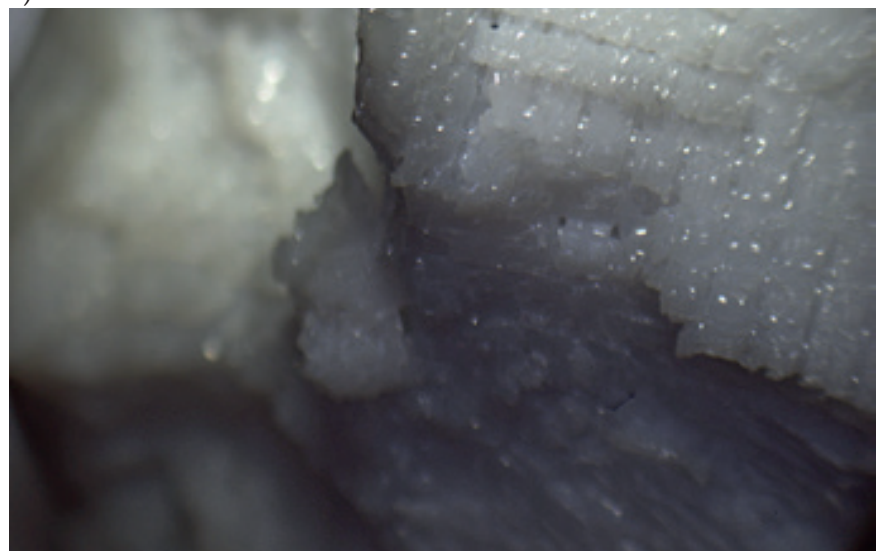

c)

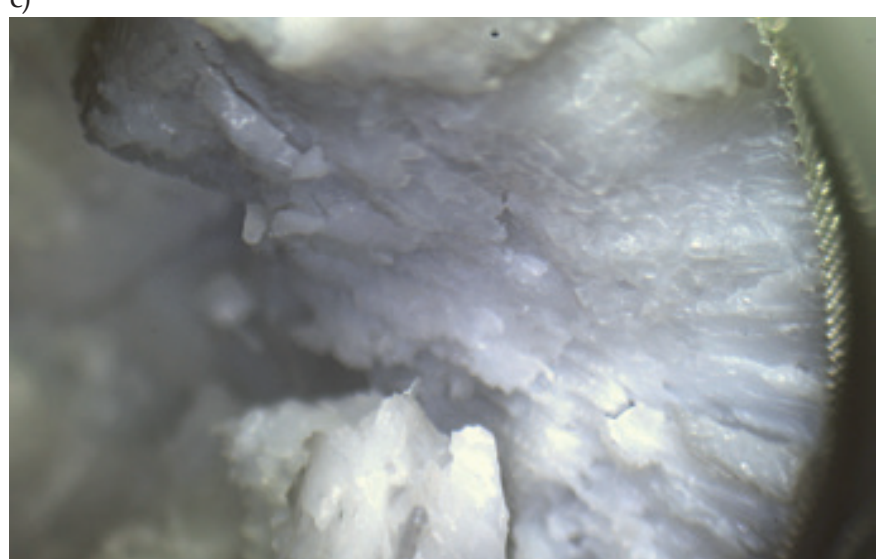

b)

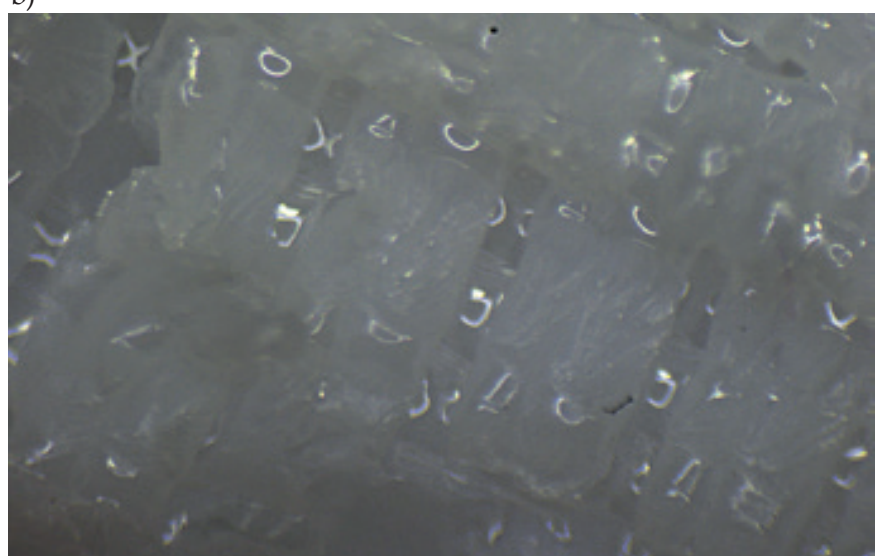

d)

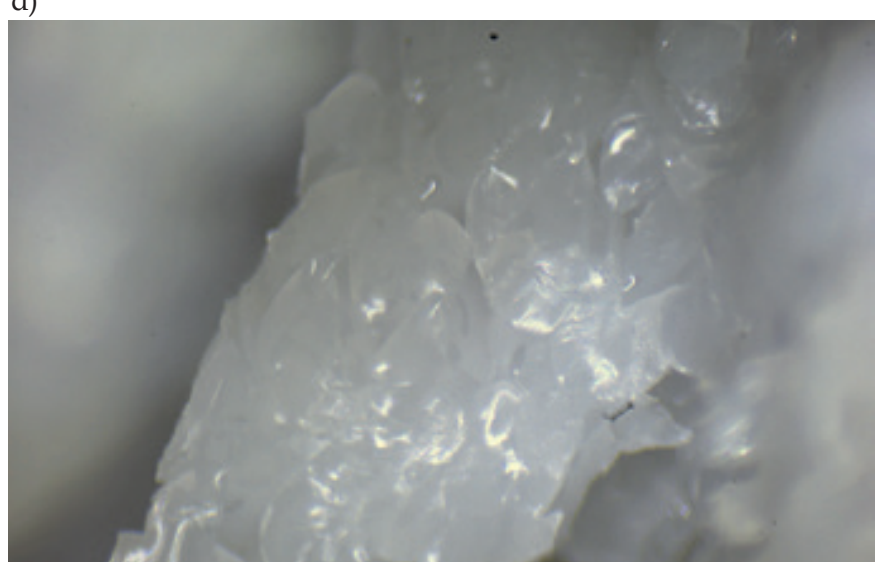

Fig. 5. Stereomicroscope images of the fracture surface after torsion test: a, b) PC sample (horizontal direction); c, d) PC sample (vertical direction) at $10 \times$ and $50 \times$ magnifications, respectively

\section{CONCLUSIONS}

For the layered thermoplastic polymer extrusion method (FDM/FFF), the direction of applying the layers has a significant influence on the structure and torsional torque. The lowest torsional torque was characteristic for samples which layers are manufactured in a plane perpendicular to the axis of rotation during load application, which indicates the lowest torsional strength.

The samples for which the layers are applied along the tracks in planes parallel to the axis of rotation are characterized by the highest torque, which indicates the highest torsional strength.

The internal structure of the model can be determined by the technological parameter of the filling degree for layered thermoplastic polymer extrusion method. For other incremental methods, for which it is not possible to manipulate the structure by technological parameters, it is possible to develop the structure directly on the 3D-CAD model of the element.

The dimensional and shape accuracy for elements manufactured by the layered thermoplastic polymer extrusion method is the highest in the plane of applying the layers. However, as shown in the previous conclusion, the torsional strength of this type of sample is the lowest, due to the lowest torsional torque.

\section{REFERENCES}

[1] Budzik G., Magniszewski M., Przeszłowski Ł. et al.: Polimery 2018, 63 (11-12), 830.

https://doi.org/10.14314/polimery.2018.11.13

[2] Oleksy M., Oliwa R., Bulanda K. et al.: Polimery 2021, $66(1), 52$.

https://doi.org/10.14314/polimery.2021.1.7

[3] Bühring J., Nuño M., Schröder K.-U.: Aerospace Science and Technology 2021, 111 (30-31), 106548.

https://doi.org/10.1016/j.ast.2021.106548

[4] Budzik G., Kubiak K., Magniszewski M. et al.: Journal of KONES 2012, 19 (2), 77.

DOI: $10.5604 / 12314005.1137895$

[5] Wu Y., Isakov D., Grant P.S.: Materials 2017, 10 (10), 1218.

https://doi.org/10.3390/ma10101218

[6] Sobolak M., Połowniak P., Cieplak M. et al.: Polimery 2020, 65 (7-8), 563.

https://doi.org/10.14314/polimery.2020.7.9

[7] Hamrol A., Gawlik J., Sładek J.: Management and Production Engineering Review 2019, 10 (3), 14. DOI: 10.24425/mper.2019.129595

[8] Turek P., Budzik G., Sęp J. et al.: Polymers 2020, 12 (12), 3029.

https://doi.org/10.3390/polym12123029 
[9] Liou F.W.: "Rapid Prototyping and Engineering Applications: A Toolbox for Prototype Development", Taylor \& Francis Group, New York 2008.

[10] Siemiński P., Budzik G.: „Techniki przyrostowe. Druk 3D. Drukarki 3D", Oficyna Wydawnicza Politechniki Warszawskiej, Warszawa 2015.

[11] Turek P., Budzik G., Przeszłowski Ł.: Polymers 2020, 12 (11), 2444. https://doi.org/10.3390/polym12112444

[12] Ko H., Witherell P., Lu Y. et al.: Additive Manufacturing 2021, 37, 101620. https://doi.org/10.1016/j.addma.2020.101620

[13] Budzik G., Przeszłowski Ł., Wieczorowski M. et al.: "Analysis of 3D printing parameters of gears for hybrid manufacturing", Materials of the $21^{\text {st }}$ International Esaform Conference on Material Forming (ESAFORM 2018), Palermo, Italy, April 23-25, 2018, pp. 140005-1-140005-6.

[14] Hopkinson N., Hague R.J.M., Dickens P.M.: „Rapid Manufacturing: An Industrial Revolution for the Digital Age", John Wiley \& Sons, Chichester, 2006.

[15] Oleksy M., Budzik G., Kozik B., Gardzińska A.: Polimery 2017, 62 (1), 3. https://doi.org/10.14314/polimery. 2017.003

[16] Kluczyński J., Śnieżek L., Grzelak K., Mierzyński J.: Materials 2018, 11 (11), 2304. https://doi.org/10.3390/ma11112304

[17] Fuad N.M., Carve M., Kaslin J., Wlodkowic D.: Micromachines 2018, 9 (3), 116. https://doi.org/10.3390/mi9030116

[18] Kolberg D., Zühlke D.: IFAC-PapersOnLine 2015, 48 (3), 1870.

https://doi.org/10.1016/j.ifacol.2015.06.359

[19] Barber N.A.: "Polyethylene Terephthalate: Uses, Properties and Degradation", Nova Science Publishers, New York 2017.

[20] Hasenauer J., Küper D., Laumeyer J.E. et al.: "10 głównych zasad stosowanych w konstrukcji detali z tworzyw sztucznych" - seria 10 artykułów wybranych dla DuPont

https://docplayer.pl/68265760-Interdyscyplinarnoscbadan-naukowych-praca-zbiorowa-pod-redakcjajaroslawa-szreka.html (date of access: 08.03.2021).

[21] https://www.igus.pl (date of access: 29.01.2021 r.).

[22] Śnieżek L., Grzelak K., Torzewski J., Kluczyński J.: "Study of the mechanical properties components made by SLM additive manufacturing", Materials of the $11^{\text {th }}$ International Conference on Intelligent Technologies in Logistics and Mechatronics Systems (ITELMS'2016), Panevezys, Lithuania, April 28-29, 2016, pp. 145-153.

[23] Quan Z., Suhr J., Yu J. et al.: Composite Structures 2018, $184,917$.

https://doi.org/10.1016/j.compstruct.2017.10.055

[24] Krawiec P., Czarnecka-Komorowska D., Warguła Ł., Wojciechowski S.: Materials 2021, 14 (7), 1682. https://doi.org/10.3390/ma14071682

Received 20 IV 2021.

\section{Rapid Communications}

Przypominamy Autorom, że publikujemy artykuły typu Rapid Communications - prace oryginalne wyłącznie w języku angielskim (o objętości 4-5 stron maszynopisu z podwójną interlinią, zawierające 2-3 rysunki lub 1-2 tabele), którym umożliwiamy szybką ścieżkę druku (do 3 miesięcy od chwili ich otrzymania przez Redakcję). Artykuł należy przygotować wg wymagań redakcyjnych zamieszczonych we wskazówkach dla P.T. Autorów.

We remind Authors that we publish articles of the Rapid Communications type - the original papers, in English only (with a volume of 4-5 pages of double-spaced typescript, containing 2-3 figures or 1-2 tables), which allow a fast print path (up to 3 months from when they are received by the Editorial Board). The article should be prepared according to the editorial requirements included in the Guide for Authors. 